\title{
Tex10 promotes stemness and EMT phenotypes in esophageal squamous cell carcinoma via the Wnt/ $\beta$-catenin pathway
}

\author{
XIAOCONG XIANG $^{1 *}$, RONG XIONG $^{1 *}$, CHUNLEI YU $^{2}$, LI DENG $^{1}$, JUN BIE $^{3}$, DONGQIN XIAO $^{1}$,

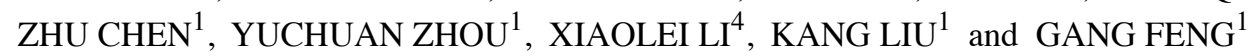 \\ ${ }^{1}$ Institute of Tissue Engineering and Stem Cells, Nanchong Central Hospital, The Second Clinical Medical College, \\ North Sichuan Medical College; ${ }^{2}$ Institute of Materia Medica, School of Pharmacy, North Sichuan Medical College; \\ Departments of ${ }^{3}$ Oncology, and ${ }^{4}$ Thoracic Surgery, Nanchong Central Hospital, The Second Clinical Medical College, \\ North Sichuan Medical College, Nanchong, Sichuan 637000, P.R. China
}

Received March 30, 2019; Accepted September 25, 2019

DOI: $10.3892 /$ or.2019.7376

\begin{abstract}
A previous study by our group suggested that testis expressed 10 (Tex10) contributes to tumor progression by promoting stem cell-like features in hepatocellular carcinoma. However, the relevance of pluripotency factor Tex10 in esophageal squamous cell carcinoma (ESCC) has remained elusive. The objective of the present study was to investigate the role of Tex10 in ESCC. For this purpose, the mRNA and protein expression of Tex10 was detected by reverse transcription-quantitative PCR, western blot analysis and immunohistochemistry. In a loss-of-function experiment, EC109 cells were transfected with lentiviral vectors containing Tex10 short hairpin RNA or negative control. Cell proliferation was assessed using a Cell Counting kit-8, and flow cytometry was used to analyze apoptosis and the cell cycle. Transwell assays were employed to examine the migratory and invasive capacity, and a sphere formation assay was performed to assess the clonogenicity of the EC109 cells. The results revealed that the elevated expression of Tex 10 was positively associated with malignancy and with epithelial-mesenchymal transition (EMT)-associated mesenchymal markers in human ESCC specimens. The knockdown of Tex 10 led to the inhibition of cell proliferation, the induction of apoptosis and cell cycle arrest, and decreased the stemness, migratory and invasive capacity of the EC109 cells. Furthermore, the silencing of Tex10 enhanced the sensitivity of the ESCC cells to 5-fluorouracil. In addition, the present study revealed that Tex 10 plays an essential role in
\end{abstract}

Correspondence to: Dr Gang Feng, Institute of Tissue Engineering and Stem Cells, Nanchong Central Hospital, The Second Clinical Medical College, North Sichuan Medical College, 97 Renmin South Road, Nanchong, Sichuan 637000, P.R. China

E-mail: fenggangncch@163.com

${ }^{*}$ Contributed equally

Key words: testis expressed 10, esophageal squamous cell carcinoma, epithelial-mesenchymal transition, stemness, $\beta$-catenin regulating EMT via the activation of $\mathrm{Wnt} / \beta$-catenin signaling. On the whole, the findings of the present study suggest that the downregulation of Tex10 in ESCC specimens is significantly associated with tumor malignancy, and that Tex10 promotes stem cell-like features and induces the EMT of ESCC cells through the enhancement of $\mathrm{Wnt} / \beta$-catenin signaling.

\section{Introduction}

Esophageal cancer is one of the most malignant tumor types worldwide, ranking third in incidence and fourth in cancer-related mortality in China (1). According to the latest statistics, 258,000 new cases of esophageal cancer and $\sim 193,000$ associated deaths were registered in 2014 in China (2). The major pathological type is squamous cell carcinoma, which progresses rapidly with a poor prognosis, and the 5-year survival rate is only $10-25 \%(3,4)$. To date, the mechanisms responsible for the occurrence and development of esophageal squamous cell carcinoma (ESCC) remain to be fully elucidated, and its treatment lacks specific molecular targets and effective therapeutic drugs.

Testis expressed 10 (Tex10), a member of the 5 friends of methylated chtop and Rix complexes, has essential roles in transcriptional regulation and ribosome biogenesis, as well as the cell cycle (5-7). Most importantly, as a new stemness factor, Tex10 plays an essential role in the establishment and maintenance of pluripotency $(8,9)$. A previous study by our group demonstrated for the first time (to the best of our knowledge) that Tex10 plays an important role in the tumorigenesis of hepatocellular carcinoma (HCC) by promoting cancer stem cell (CSC) properties and chemoresistance (10).

Several studies have demonstrated that epithelialmesenchymal transition (EMT) is linked to the acquirement of cancer stem cell-like phenotypes, which may be a necessary step in the process of tumor metastasis $(11,12)$. Cancer cells that have gained the ability to move and invade have undergone EMT; however, only a small number of these cells may be transplanted into distant organs and form metastases through mesenchymal-epithelial transition, and the population of these cells is considered to be CSCs $(13,14)$. The acquisition of stem cell-like properties is accompanied by the activation of 
EMT during tumor metastasis and the activation of EMT contributes to the generation and maintenance of CSCs (15). In the present study, it was hypothesized that Tex10 is involved in ESCC metastasis through the regulation of EMT and stemness.

Despite the important role of Tex10 in cancer development, the functional role of Tex10 in ESCC has not yet been previously investigated, at least to the best of our knowledge. The present study thus aimed to investigate the expression pattern and function of Tex10 in ESCC development and to determine the effect of Tex10 on the migration, invasion, stemness and EMT of ESCC cells. Furthermore, the present study attempted to unravel the exact regulatory mechanisms of stemness and EMT, focusing on the $\mathrm{Wnt} / \beta$-catenin pathway. The results demonstrated that Tex10 may be a potential drug target for ESCC therapy and the prevention of metastasis.

\section{Materials and methods}

Patients and tumor samples. The expression levels of Tex10 were measured using immunohistochemistry (IHC) in human ESCC tissues and their matched adjacent non-cancerous tissues that were collected from Nanchong Central Hospital (Nanchong, China) from June, 2017 to June, 2018. A total of 7 patients ( 3 females, 4 males) were enrolled in this study, with a median age of 57 years (range, $48-66$ years). The basic clinical characteristics of the patients are presented in Table I. Consent was obtained from all of the patients prior to enrolment. The present study was approved by the Ethics Committee of the North Sichuan Medical College [NSMC (Nanchong, China)] and the Ethical Committee of Nanchong Central Hospital (Nanchong, China), and performed in accordance with the Declaration of Helsinki.

ESCC cell lines and cell culture. The human ESCC cell line, EC109, used in the present study was purchased from the Cell Resource Center of the Shanghai Institute of Life Sciences, Chinese Academy of Sciences and authenticated by short-tandem repeat testing. EC109 was mycoplasma-free and cultured in RPMI-1640 medium (Gibco; Thermo Fisher Scientific, Inc.) containing 10\% fetal bovine serum (Gibco; Thermo Fisher Scientific, Inc.) and $1 \%$ penicillin-streptomycin (Gibco; Thermo Fisher Scientific, Inc.) at $37^{\circ} \mathrm{C}$ in an incubator with $5 \% \mathrm{CO}_{2}$.

Construction of lentivirus and stable transfection into cell lines. The lentiviral vector encoding the human Tex10 gene was constructed by Genechem Co., Ltd. The target sequences of Tex10-short hairpin (sh)RNA are described in a previous study (10). The target sequences were as follows: shTex10, 5'-AGCTACTGCCCTCCGAATTTA-3'; and shRNA control, 5'-TTCTCCGAACGTGTCACGT-3'. Lentiviral vector encoding shTex10 and non-targeting shRNA were designated as shTex10 and scramble, respectively. The EC109 cells were transfected with recombinant lentivirus-transducing units in the presence of polybrene $(6 \mu \mathrm{g} / \mathrm{ml})$ according to the manufacturer's instructions and stable Tex10 knockdown clones (shTex10-C1, shTex10-C2) were selected with $2.5 \mu \mathrm{g} / \mathrm{ml}$ puromycin (A1113803; Gibco; Thermo Fisher Scientific, Inc.). The selected pools of knockdown cells were then collected and cultured within 10 passages for use in the subsequent experiments.
Reverse transcription-quantitative PCR (RT-qPCR). Total RNA was extracted from the EC109 cells using TRIzol reagent (Invitrogen; Thermo Fisher Scientific, Inc.) and reverse transcribed using the ThermoScript RT-PCR system (cat. no. 11731015; Invitrogen; Thermo Fisher Scientific, Inc.) according to the manufacturer's protocol. qPCR with SYBR-Green (cat. no. 1708886; Bio-Rad Laboratories, Inc.) was performed on an iQ5 Multicolor Real-Time PCR Detection system (Bio-Rad Laboratories, Inc.). According to a previously described method (16), the PCR conditions were as follows: $95^{\circ} \mathrm{C}$ for $5 \mathrm{~min}$ followed by 40 cycles of $95^{\circ} \mathrm{C}$ for $30 \mathrm{sec}$ and $57^{\circ} \mathrm{C}$ for $30 \mathrm{sec}$. GAPDH was used as an internal control. All reactions were run in triplicate and quantified with $2-\Delta \Delta \mathrm{Cq}$ (17). The sequences of the PCR primers are listed in Table II.

IHC. IHC was performed as described in a previous study by our group (16). ESCC sections of $3 \mu \mathrm{m}$ thickness were deparaffinized with xylene and antigen retrieval was then performed with $0.01 \mathrm{M}$ sodium citrate buffer ( $\mathrm{pH}$ 6.0) in a pressure cooker for 3 min. Endogenous peroxidase was blocked with $3 \% \mathrm{H}_{2} \mathrm{O}_{2}$ for $10 \mathrm{~min}$, and the membrane was then permeated with $0.1 \%$ Triton X-100 for $10 \mathrm{~min}$, followed by the blocking of non-specific binding sites with $3 \%$ bovine serum albumin for $1 \mathrm{~h}$ at room temperature. The sections were then incubated with anti-Tex10 polyclonal antibody (cat. no. 17372-1-AP; 1:100 dilution; Proteintech Group, Inc.) at $4^{\circ} \mathrm{C}$ overnight, followed by incubation with a horseradish peroxidase (HRP)-conjugated secondary antibody [cat. no. PV-6001; Zhongshang Goldenbridge (ZSGB)-Bio] for $1 \mathrm{~h}$ at room temperature. The slides were developed with diaminobenzidine substrate (cat. no. ZLI-9017; ZSGB-Bio) and counterstained with hematoxylin for $2 \mathrm{~min}$ at room temperature (cat. no. ZLI-9608; ZSGB-Bio).

Western blot analysis. EC109 cells stably expressing shTex10 or non-target shRNA were collected and lysed with radioimmunoprecipitation assay buffer (Keygen Biotech) supplemented with protease inhibitor cocktail (Roche Applied Science). Proteins from the lysed cells were fractionated by $10 \%$ SDS-PAGE and subsequently transferred onto nitrocellulose membranes (Hybond C; GE Healthcare Life Sciences). Non-specific binding sites were blocked with $5 \%$ non-fat milk at room temperature for $1 \mathrm{~h}$ and the membranes were incubated with the following antibodies overnight at $4^{\circ} \mathrm{C}$ : Anti-Tex10 (cat. no. 17372-1-AP; dilution, 1:250; Proteintech Group, Inc.), Bcl-2 (cat. no. ET1702-53; dilution, 1:500), Slug (cat. no. EM1706-65; dilution, 1:1,000), $\beta$-catenin (cat. no. ET1601-5; dilution, 1:1,000), transcription factor 4 (TCF4; cat. no. R1401-11; dilution, 1:500), cyclin D1 (cat. no. ET1601-31; dilution, 1:1,000), CD44 (cat. no. ET1609-74; dilution, 1:1,000), CD24 (cat. no. 0804-4; dilution, 1:1,000), vimentin (cat. no. M1412-1; dilution, 1:1,000) (all from HuaBio Inc.), bHLH transcription factor (c-Myc; cat. no. ab32072; dilution, 1:2,000) and GAPDH (cat. no. ab9485; dilution, 1:2,000; both from Abcam). The membranes were then washed and incubated with HRP-conjugated goat anti-rabbit (cat. no. A4914; dilution, 1:10,000) or goat anti-mouse (cat. no. A4416; dilution, 1:10,000) antibodies (both from Sigma-Aldrich; Merck KGaA). The bands were visualized using enhanced 
Table I. Baseline characteristics of the patients included in the study.

\begin{tabular}{lcclccccc}
\hline & & & & & \multicolumn{3}{c}{ TNM } \\
Case & Sex & $\begin{array}{c}\text { Age } \\
\text { (years) }\end{array}$ & Stage & $\begin{array}{c}\text { Tumor } \\
\text { grade }\end{array}$ & T & N & M \\
\hline 1 & F & 48 & IB & 1 & 1 & 0 & 0 \\
2 & M & 50 & IIIA & 1 & 3 & 1 & 0 \\
3 & M & 61 & IIB & 3 & 3 & 0 & 0 \\
4 & M & 60 & IB & 2 & 1 & 0 & 0 \\
5 & F & 52 & IIIA & 3 & 3 & 1 & 0 \\
6 & F & 66 & IIA & 2 & 3 & 0 & 0 \\
7 & M & 62 & IIIA & 3 & 2 & 2 & 0 \\
\hline
\end{tabular}

F, female; $M$, male.

chemiluminescence reagents (cat. no. WP20005; Thermo Fisher Scientific, Inc.).

Cell proliferation assay. The proliferation of the ESCC cells was measured using the Cell Counting kit-8 (CCK-8) assay (Keygen Biotech). The cells ( $2 \times 10^{3} /$ well) were seeded into 96-well plates and observed every day, and at specific time-points, $10 \mu \mathrm{l}$ CCK- 8 and $100 \mu \mathrm{l}$ fresh medium were added to each well. Following incubation for $1.5 \mathrm{~h}$ at $37^{\circ} \mathrm{C}$, the absorbance was measured at $450 \mathrm{~nm}$ using a microplate reader (ST-360; KHB). Each condition was assayed in triplicate.

Flow cytometric evaluation of apoptosis. The shTex10- and scramble EC109-transfected cells were treated with $100 \mu \mathrm{g} / \mathrm{ml}$ 5-fluorouracil (F5130; Sigma-Aldrich; Merck KGaA) for 48 h, and the cells were then collected and washed with ice-cold PBS. The analysis was performed with an Annexin V-FITC reagent kit (cat. no. A211-01; Vazyme Biotech Co., Ltd.). The cells were re-suspended to a final concentration of $1 \times 10^{6}$ cells $/ \mathrm{ml}$ in Annexin V-binding buffer and incubated with AnnexinV-FITC in the presence of propidium iodide for $15 \mathrm{~min}$ at $4^{\circ} \mathrm{C}$. Samples were analyzed using a BD FACSCalibur flow cytometer (BD Biosciences) and subsequent analyses were performed with FlowJo software (FlowJo 10.5, LLC).

Cell cycle analysis. The EC109 cells cultured in 6-well plates were digested with trypsin (Gibco; Thermo Fisher Scientific, Inc.), washed with PBS and then fixed with $75 \%$ ethanol at $-20^{\circ} \mathrm{C}$ overnight. Subsequently, the cells were washed with PBS and incubated with $50 \mathrm{mg} / \mathrm{ml}$ propidium iodide containing $80 \mathrm{mg} / \mathrm{ml}$ RNase (cat. no. KGA512; Keygen Biotech) in PBS for $30 \mathrm{~min}$. Fluorescence-assisted cell sorting data were collected on a BD FACSCalibur flow cytometer (BD Biosciences) and analyzed with FlowJo software (FlowJo10.5, LLC).

In vitro migration and invasion assays. The migration or invasion assays were performed using polycarbonate Transwell filter chambers ( $8 \mu \mathrm{m}$ pore size; cat. no. 3422 ; Corning Inc.) and the inserts were coated with or without Matrigel ${ }^{\circledR}$ (BD Biosciences). The scramble- or Tex10 shRNA-transfected
Table II. Sequences of primers used for RT-qPCR.

\begin{tabular}{|c|c|}
\hline Gene & Primer sequence $\left(5^{\prime}-3^{\prime}\right)$ \\
\hline \multirow[t]{2}{*}{ Tex10 } & F: TTGCAACTTGCTCATCTTGG \\
\hline & R: AGAGTCTGCAGGGAGAACCA \\
\hline \multirow[t]{2}{*}{ GAPDH } & F: TGCACCACCAACTGCTTAGC \\
\hline & R: GGCATGGACTGTGGTCATGAG \\
\hline \multirow[t]{2}{*}{ Sox 2} & F: CGCAGACCTACATGAACG \\
\hline & R: CCCTGGAGTGGGAGGAA \\
\hline \multirow[t]{2}{*}{ Bmi1 } & F: CAACTGGTTCGACCTTTGCAGATA \\
\hline & R: GATGTGCCAATTGCTTCTAATGGA \\
\hline \multirow[t]{2}{*}{ Nanog } & F: AATACCTCAGCCTCCAGCAGATG \\
\hline & R: TGCGTCACACCATTGCTATTCTTC \\
\hline \multirow[t]{2}{*}{ Oct4 } & F:CTTGCTGCAGAAGTGGGTGGAGGAA \\
\hline & R: CTGCAGTGTGGGTTTCGGGCA \\
\hline \multirow[t]{2}{*}{ c-Myc } & F: GGCCGCTGCCAAACTGGTCT \\
\hline & R: TGGGCGAGCTGCTGTCGTTG \\
\hline \multirow[t]{2}{*}{ ABCG2 } & F: ACAACCATTGCATCTTGTCTGTC \\
\hline & R: GCTGCAAAGCCGTAAATCCATATC \\
\hline \multirow[t]{2}{*}{ E-cadherin } & F: GGTGAGGGGTTAAGCACAACA \\
\hline & R: ACGACGTTAGCCTCGTTCTC \\
\hline \multirow[t]{2}{*}{ Vimentin } & F: ACAACCTGGCCGAGGACATC \\
\hline & R: GACGTGCCAGAGACGCATTG \\
\hline \multirow[t]{2}{*}{ Slug } & F: CGGACCCACACATTACCTTGT \\
\hline & R: AAAAAGGCTTCTCCCCCGTG \\
\hline \multirow[t]{2}{*}{ Snail } & F: ATGCACATCCGAAGCCACAC \\
\hline & R: TGCAGTGGGGACAGGAGAAG \\
\hline \multirow[t]{2}{*}{ Twist1 } & F: GACCTAGATGTCATTGTTTCCAGAG \\
\hline & R: CCCACGCCCTGTTTCTTTGAA \\
\hline \multirow[t]{2}{*}{$\beta$-catenin } & F: CGCTGGATTTTCAAAACAGT \\
\hline & R: CTGAGGAGCAGCTTCAGTCC \\
\hline \multirow[t]{2}{*}{ CD133 } & F: TGGATGCAGAACTTGACAACGT \\
\hline & R: ATACCTGCTACGACAGTCGTGGT \\
\hline \multirow[t]{2}{*}{ CD24 } & F: TGAAGAACATGTGAGAGGTTTGAC \\
\hline & R: GAAAACTGAATCTCCATTCCACAA \\
\hline \multirow[t]{2}{*}{ CD44 } & F: GCAGCCTCAGCTCATACCAG \\
\hline & R: TGACTGGAGTCCATATCCATCCTT \\
\hline
\end{tabular}

Tex10, testis expressed 10; GAPDH, glyceraldehyde-3-phosphate dehydrogenase; Sox2, SRY (sex determining region Y)-box 2; Bmi1, polycomb ring finger; Oct4, octamer-binding transcription factor 4; c-Myc, bHLH transcription factor; E-cadherin, epithelial cadherin; ABCG2, ATP binding cassette subfamily G member 2; Slug, snail family transcriptional repressor 2; Twist1, twist family bHLH transcription factor $1 ; \mathrm{F}$, forward; $\mathrm{R}$, reverse.

EC109 cells $\left(5 \times 10^{4}\right)$ in $100 \mu 1$ serum-free medium were added to the top chamber, whereas the bottom chamber was filled with $500 \mu \mathrm{l}$ medium containing $10 \%$ serum. Following incubation for $48 \mathrm{~h}$ at $37^{\circ} \mathrm{C}$, all of the non-migrating or non-invading cells were removed, and cells on the lower membrane of the inserts were stained with $0.1 \%$ crystal violet (KGA229, Keygen Biotech) at room temperature for $5 \mathrm{~min}$. The number of cells that had migrated or invaded was counted under a microscope (ECLIPSE TS100, Nikon) and images were captured. Each 
experimental condition was performed with triplicate filters and the experiments were repeated 3 times.

Sphere formation assay. The spheroid formation assay was based on a previously described method (10). The EC109 cells were seeded onto ultralow attachment 6-well plates (Corning Inc.) and cultured in Dulbecco's modified Eagle's medium/F12 (cat. no. 10565018; Gibco; Thermo Fisher Scientific, Inc.) medium containing N2, B27 (Gibco; Thermo Scientific, Inc.), $20 \mathrm{ng} / \mathrm{ml}$ epidermal growth factor and $20 \mathrm{ng} / \mathrm{ml}$ basic fibroblast growth factor (EMD Millipore). Following 7 days of incubation at $37^{\circ} \mathrm{C}$, the spheres were counted under a microscope (DMi 8; Leica).

Drug sensitivity assay. The ESCC cells (1x104/well) were seeded into 96-well plates and a serial dilution of 5-fluorouracil (F5130; Sigma-Aldrich; Merck KGaA) ranging from 0 to $100 \mu \mathrm{g} / \mathrm{ml}$ was added to the scrambled or shTex 10 transfected EC109 cells after $24 \mathrm{~h}$. Following incubation for $72 \mathrm{~h}$ at $37^{\circ} \mathrm{C}$, as previously described $(18,19)$, cell proliferation was measured with a CCK-8 assay (KGA317s; Keygen Biotech) as described above.

Clinical dataset analysis. To assess the expression levels of Tex10 mRNA, a large cohort of patients with ESCC from the public datasets, GSE23400 and GSE20347, was analyzed in Oncomine (www.oncomine.org) according to the instructions provided.

Actin cytoskeleton staining. Actin cytoskeleton staining analyses of filamentous actin (F-actin) was performed as previously described (20). In brief, the EC109 cells stably expressing shTex10 or scrambled shRNA (1x106/well) were placed in 6-well plates. At $24 \mathrm{~h}$ after seeding, the cells were washed with PBS and fixed with $4 \%$ paraformaldehyde for $24 \mathrm{~h}$ at room temperature. The cells were subsequently incubated for 30 min with phalloidin-FITC (cat. no. CA1610; Solarbio) and DAPI (cat. no. 32670; Sigma-Aldrich; Merck $\mathrm{KGaA}$ ). Finally, the cells were washed with PBS prior to capturing of images under an inverted fluorescence microscope (DMi 8; Leica).

Statistical analysis. All experiments were performed at least 3 independent experiments independently, and all values were expressed as the means \pm standard deviation. The SPSS 20.0 software (IBM Corp.) was used for statistical analysis. A two-tailed unpaired Student's t-test with Welch correction or one-way ANOVA followed by Dunnett's adjustment (for dose-response effects) or the Bonferroni test (for multiple comparisons) was used to determine the statistical significance of the differences in the measured variables. We have specified the name of the statistical test in the figure legends. A value of $\mathrm{P}<0.05$ was considered to indicate a statistically significant difference.

\section{Results}

Tex10 expression is elevated in ESCC tissues. To determine the expression of Tex10 in ESCC and adjacent normal tissues, IHC was performed, and the results indicated that the intensity of Tex10 immunostaining in the ESCC tissues was markedly higher compared with that in the adjacent non-cancerous tissues (Fig. 1A). The expression pattern of Tex10 in ESCC was further analyzed in Oncomine, a publicly accessible cancer informatics database. The results demonstrated that the mRNA expression of Tex10 in the ESCC tissues was significantly higher compared with that in the matched non-cancerous tissues (Fig. 1B and C). Collectively, these results indicated that Tex10 is associated with ESCC.

Silencing of Tex10 reduces cell viability by suppressing proliferation, inducing cell apoptosis and blocking cell cycle progression. To investigate the biological function of Tex10 in the ESCC cells, two cell lines with stable Tex10 knockdown (shTex10-C1, shTex10-C2) were generated using a lentiviral system. Two shRNAs (scrambled, shTex10) were specifically designed and constructed, and used to transfect the EC109 cells, followed by screening with $2.5 \mu \mathrm{g} / \mathrm{ml}$ puromycin for 2 weeks. RT-qPCR and western blot analysis were performed to measure the knockdown efficiency of Tex10. The mRNA expression level of Tex10 was markedly decreased in the shTex10-transfected cells compared with the scramble shRNA-transfected cells $(\mathrm{P}<0.05$ and $\mathrm{P}<0.01$; Fig. 2A). Consistent with this finding, the decreased protein expression of Tex10 was observed in the shTex10-transfected cells (Fig. 2B). Thus, these results demonstrated that Tex10 was specifically and effectively inhibited.

Subsequently, it was determined whether Tex10 is required for the growth and apoptosis of EC109 cells. The results indicated that the silencing of Tex10 significantly inhibited the proliferation of the EC109 cells $(\mathrm{P}<0.05$ and $\mathrm{P}<0.01$; Fig. 2C). When Annexin V staining was used to assess the effects of Tex10 on the apoptosis of the EC109 cells, it was revealed that the percentages of Annexin V-positive cells were markedly higher in the shTex10 groups compared with those in the scramble groups, with $\sim 85 \%$ of the shTex 10 cells undergoing early apoptosis $(\mathrm{P}<0.01$; Fig. 2D). Furthermore, the downregulation of anti-apoptotic factor, Bcl-2, was observed following the knockdown of Tex10 (Fig. 2E). The effects of Tex10 knockdown on the cell cycle distribution were then investigated. As shown in Fig. 2F, cell cycle phase analysis indicated a decrease in the G0/G1 phase cell population and an increase in the number of cells in the G2/M and $\mathrm{S}$ phase in the shTex10 group, indicating that the ESCC cells exhibited cell cycle disorders upon the downregulation of Tex10. Taken together, these results fully demonstrate that the knockdown of Tex10 suppresses ESCC cell proliferation, induces cell apoptosis and blocks cell cycle progression.

Tex10 enhances CSC properties, including self-renewal and resistance ability. Self-renewal is a prominent feature of CSCs, and to further determine the effects of Tex10 on the self-renewal properties of ESCC cells, the sphere-formation assay was employed. The results indicated that the knockdown of Tex10 led to a considerable decrease in the number and size of spheroids $(\mathrm{P}<0.01$; Fig. 3A). Furthermore, the mRNA levels of stem the cell-specific markers, SRY-Box 2 (Sox2), Nanog and octamer-binding transcription factor 4 (Oct4), and the CSC-associated markers, c-Myc, polycomb ring finger (Bmi1), ATP binding cassette subfamily G member 2 (ABCG2), CD133, CD44 and CD24, decreased significantly in the EC109 
A
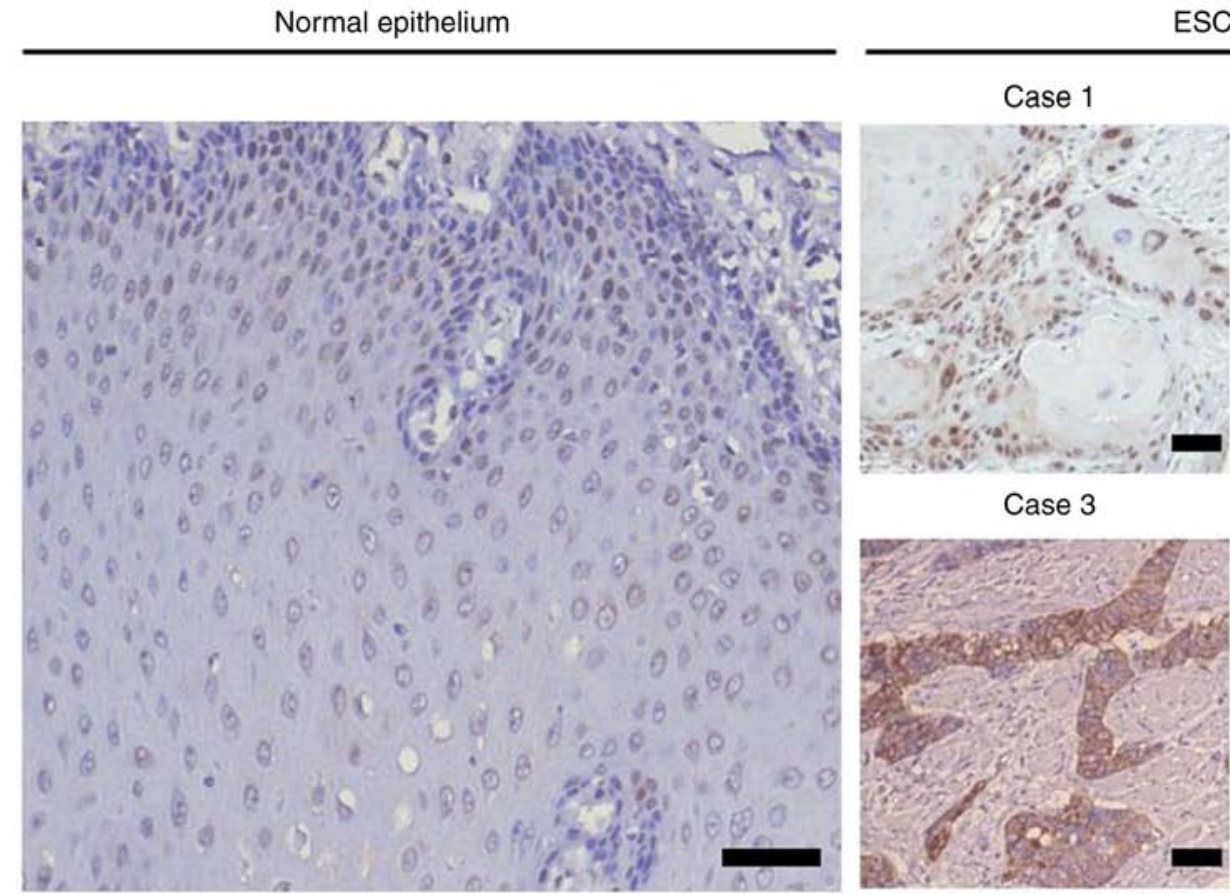

Case 3
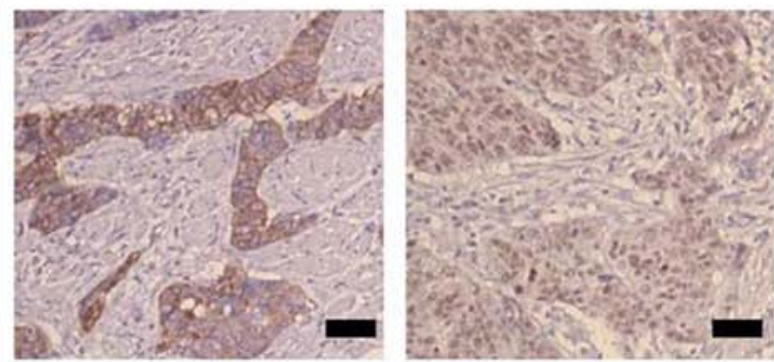

B

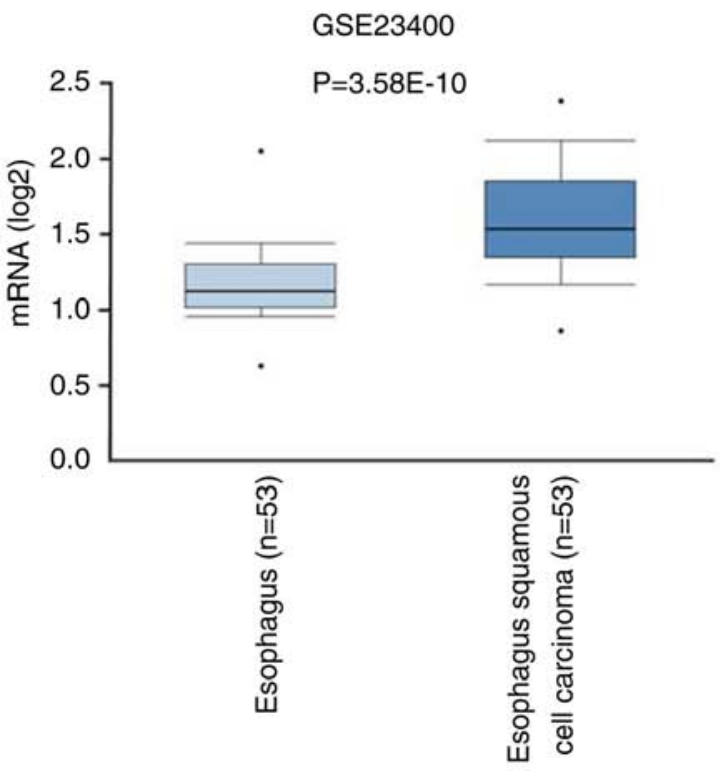

C

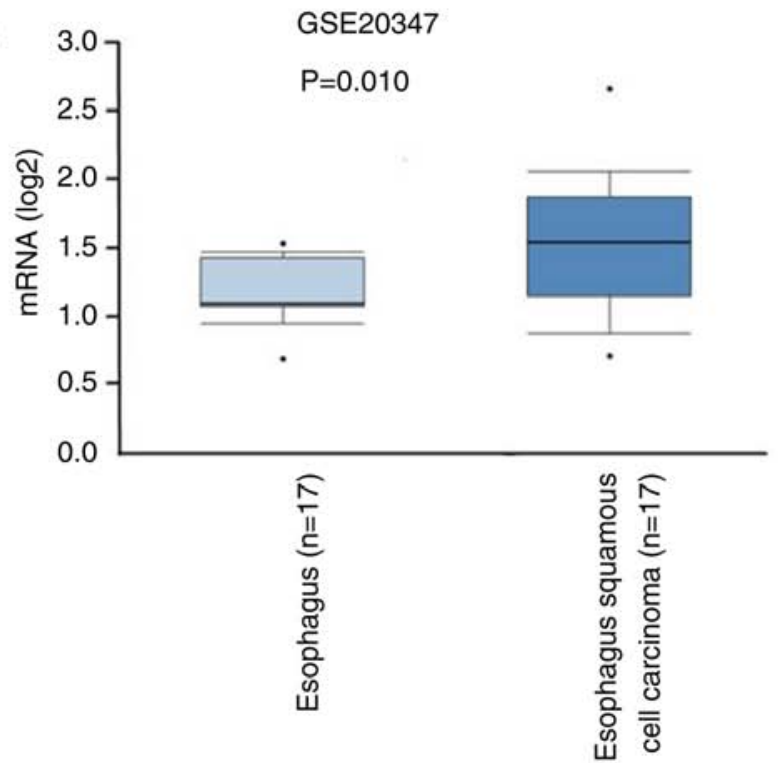

Figure 1. Tex10 is highly expressed in ESCC tissues. (A) Representative photomicrographs of immunohistochemical staining for Tex10 in carcinoma (cases 1 , 2,3 and 6) and the adjacent normal tissues of ESCC patients. Scar bar: $100 \mu \mathrm{m}$. (B and C) Box plots showing Tex 10 gene expression levels in 53 patients and 17 patients from public dataset (GSE2340 and GSE20347), respectively, analyzed in Oncomine (www.oncomine.org). Dataset accession numbers and P-values are shown. Tex10, testis expressed 10; ESCC, esophageal squamous cell carcinoma.

cells following the knockdown of Tex10 $(\mathrm{P}<0.05$ and $\mathrm{P}<0.01$; Fig. 3B). Furthermore, the protein expression levels of CD44 and $\mathrm{CD} 24$ were downregulated following the knockdown of Tex10 (Fig. 3C). The present study therefore established that Tex10 silencing severely impairs the self-renewal capacity of CSCs. The existence of CSCs is the cause of chemotherapeutic failure (21), and as one of the major characteristics of CSCs, resistance to 5-fluorouracil is an insuperable barrier for patients with ESCC (18).

Thus, to explore the potential role of Tex10 in promoting chemoresistance, the effect of 5 -fluorouracil on the survival of EC109 cells in which Tex10 was knocked down was further investigated. Following treatment with various concentrations of 5 -fluorouracil for $72 \mathrm{~h}$, the shTex10 group was observed to be more sensitive to increasing concentrations of 5-fluorouracil compared to the scramble group $\left(\mathrm{P}<0.01\right.$; Fig. 3D), and a significantly lower $\mathrm{IC}_{50}$ value of 5 -fluorouracil of $5.3 \pm 0.94 \mu \mathrm{g} / \mathrm{ml}$ in the shTex10-transfected EC109 cells compared with $87.5 \pm 12.35 \mu \mathrm{g} / \mathrm{ml}$ in the scramble shRNA-transfected cells was obtained. Furthermore, flow cytometric analysis of the scramble shRNA- and shTex10-transfected EC109 cells treated with $100 \mu \mathrm{g} / \mathrm{ml}$ 5 -fluorouracil for $48 \mathrm{~h}$ indicated that a larger percentage of shTex10-transfected EC109 cells underwent apoptosis when exposed to 5-fluorouracil ( $\mathrm{P}<0.01$; Fig. 3E). In summary, these results indicate that Tex 10 promotes the self-renewal capacity 


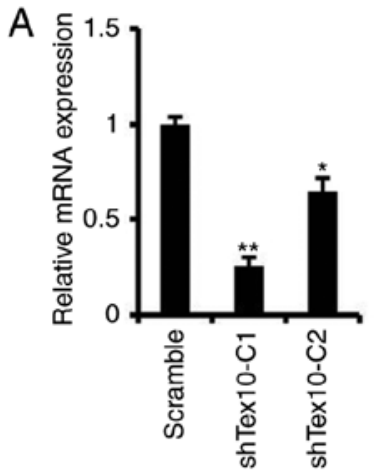

D
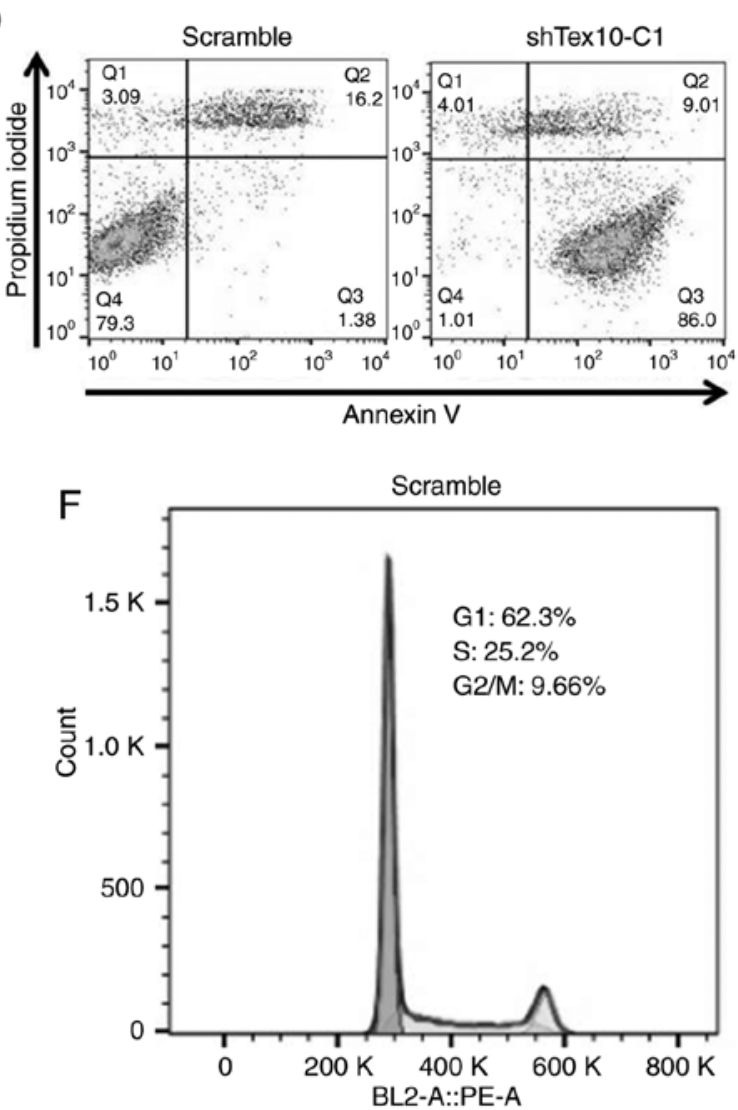

B

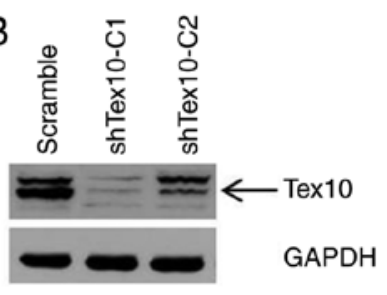

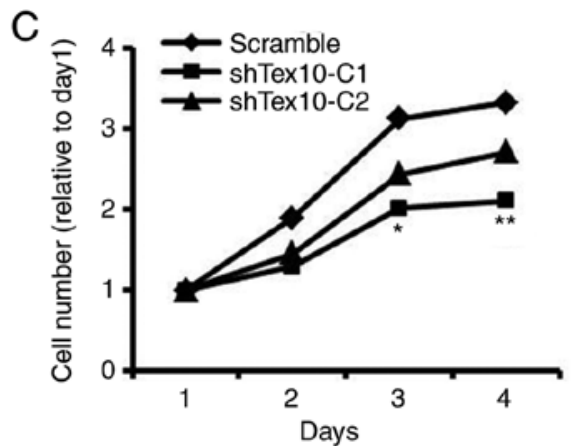
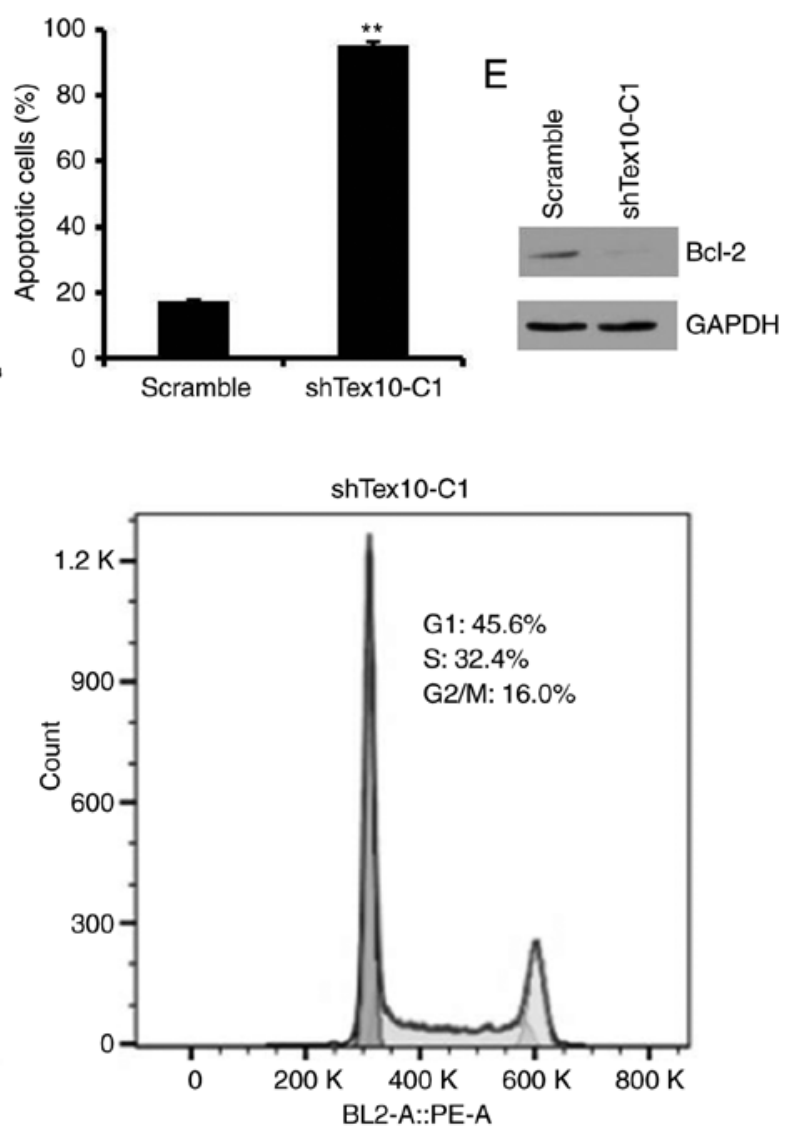

Figure 2. Silencing of Tex10 inhibits cell proliferation, induces apoptosis and arrests the cell cycle in EC109 cells. (A) The mRNA level of Tex10 was verified in sorted EC109 cells following transfection. Error bars represent the means \pm SD of 3 independent experiments. One-way ANOVA followed by the Bonferroni test was used to determine the statistical significance of the differences. ${ }^{*} \mathrm{P}<0.05$ and ${ }^{* *} \mathrm{P}<0.01$, significant difference vs. scramble group. (B) Western blot analysis for the detection of Tex10 protein expression in the constructed EC109 cells. GAPDH was used as a loading control. (C) Cell viability was evaluated at the indicated time points using CCK-8 assay. One-way ANOVA followed by the Bonferroni test was used to determine statistical significance. ${ }^{*} \mathrm{P}<0.05$ and ${ }^{* *} \mathrm{P}<0.01$, significant difference vs. scramble group. (D) Cell apoptosis was measured by flow cytometric analysis. Error bars represent the means $\pm \mathrm{SD}$ of 3 independent experiments. Two-tailed unpaired Student's t-test was used to determine statistical significance. ${ }^{* *} \mathrm{P}<0.01$, significant difference vs. scramble group. (E) Protein expression levels of Bcl-2 after Tex10 knockdown. (F) Cell cycle was examined by flow cytometric analysis. Tex10, testis expressed 10 .

and drug resistance of ESCC cells, the two major functional characteristics of CSCs.

Silencing of Tex10 suppresses the migration and invasion of ESCC cells in vitro. To further examine the role of Tex10 in invasion and metastasis in ESCC, the migratory and invasive capacity of the ESCC cells in which Tex10 was silenced was assessed. Transwell assays indicated that the silencing of Tex10 markedly suppressed the migration of the EC109 cells. Furthermore, the invasion of the EC109 cells significantly decreased following Tex10 knockdown. These results indicate that Tex10 plays a role in the migration and invasion of EC109 cells $(\mathrm{P}<0.05$; Fig. 4).

Tex10 promotes EMT by enhancing Wnt/ $\beta$-catenin signaling during ESCC tumorigenesis. It was observed that the morphology of the EC109 cells with stable Tex10 knockdown changed from a spindle-like mesenchymal morphology to an epithelial cobblestone-like appearance (Fig. 5A). The morphological changes were further supported by phalloidin staining, 

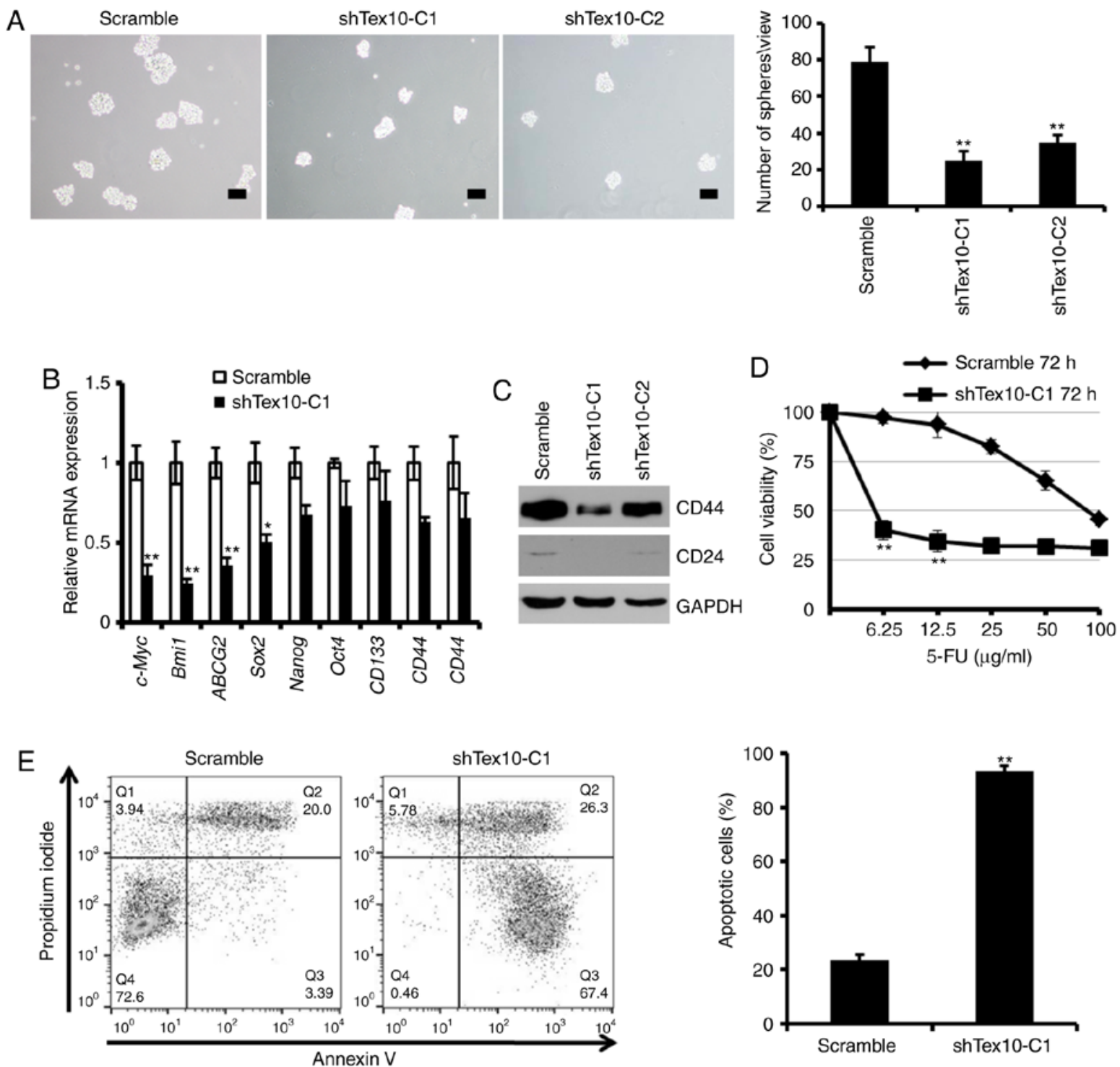

Figure 3. Tex10 is necessary for the maintenance of CSC properties. (A) Representative images of spheres formed by different groups of EC109 cells. Histograms indicate the mean number of spheres. One-way ANOVA followed by the Bonferroni test was used to determine the statistical significance of the differences. ${ }^{* *} \mathrm{P}<0.01$, significant difference vs. scramble group. Scar bar, $100 \mu \mathrm{m}$. (B) RT-qPCR analysis of the expression of pluripotency-associated markers, including Nanog, Oct4, Sox2, Bmi1, ABCG2, c-Myc, CD133, CD44 and CD24 in different groups of EC109 cells. Error bars represent the means \pm SD of 3 independent experiments. The two-tailed unpaired Student's t-test was used to determine statistical significance. "P<0.05 and ${ }^{* * *} \mathrm{P}<0.01$, significant difference vs. scramble group. (C) Tex10 knockdown decreased CD44 and CD24 protein expression levels in EC109 cells. (D) shTex10-C1 and scramble EC109 cells were treated with the indicated concentrations of 5 -fluorouracil $(0-100 \mu \mathrm{g} / \mathrm{ml})$ for $72 \mathrm{~h}$. Cell viability was analyzed by CCK- 8 assay. The OD value of untreated cells was taken as $100 \%$ viable cells. Data are presented as the means \pm SD; $n=3$; The two-tailed unpaired Student's t-test was used to determine statistical significance. ${ }^{* *} \mathrm{P}<0.01$, significant difference vs. scramble group. (E) Representative apoptosis analyses of EC109 cells treated with 5 -fluorouracil for $48 \mathrm{~h}$. The values indicate the means \pm SD of 3 independent experiments. The two-tailed unpaired Student's t-test was used to determine statistical significance. ${ }^{* *} \mathrm{P}<0.01$, significant difference vs. scramble group. Tex10, testis expressed 10; Oct4, octamer-binding transcription factor 4; Sox2, SRY-Box 2; Bmi1, polycomb ring finger; ABCG2, ATP binding cassette subfamily G member 2; c-Myc, bHLH transcription factor.

indicating that the EC109 cells in which Tex10 was silenced exhibited a cobblestone-like shape and shrunken F-actin fibers compared to the scrambled shRNA-transfected cells (Fig. 5A). Considering the morphological changes of the ESCC cells, it was hypothesized that an abnormally high level of Tex10 may trigger EMT. E-cadherin, vimentin, Snail, Slug, Twist1 and $\beta$-catenin have been frequently identified as specific markers for the EMT process $(22,23)$. Therefore, it was further assessed whether Tex10 had an impact on the expression of EMT markers by quantifying the expression levels of these markers by RT-qPCR and western blot analysis. As presented in Fig. 5B, the mRNA levels of E-cadherin in the cells in which
Tex10 was silenced were significantly increased, whereas the expression levels of Slug and $\beta$-catenin in the Tex10-silenced cells were significantly decreased; western blot analysis revealed that the protein levels of Slug and $\beta$-catenin were markedly downregulated, while the expression of vimentin was not affected (Fig. 5C). These results thus suggest that the downregulation of Tex10 attenuates EMT in ESCC.

Since Wnt/ $\beta$-catenin signaling plays an essential role in promoting tumor invasion and metastasis, and is one of the major mechanisms regulating EMT, it was investigated whether Tex10 promotes ESCC metastasis via the Wnt/ $\beta$-catenin pathway. For this, the expression of downstream target genes 

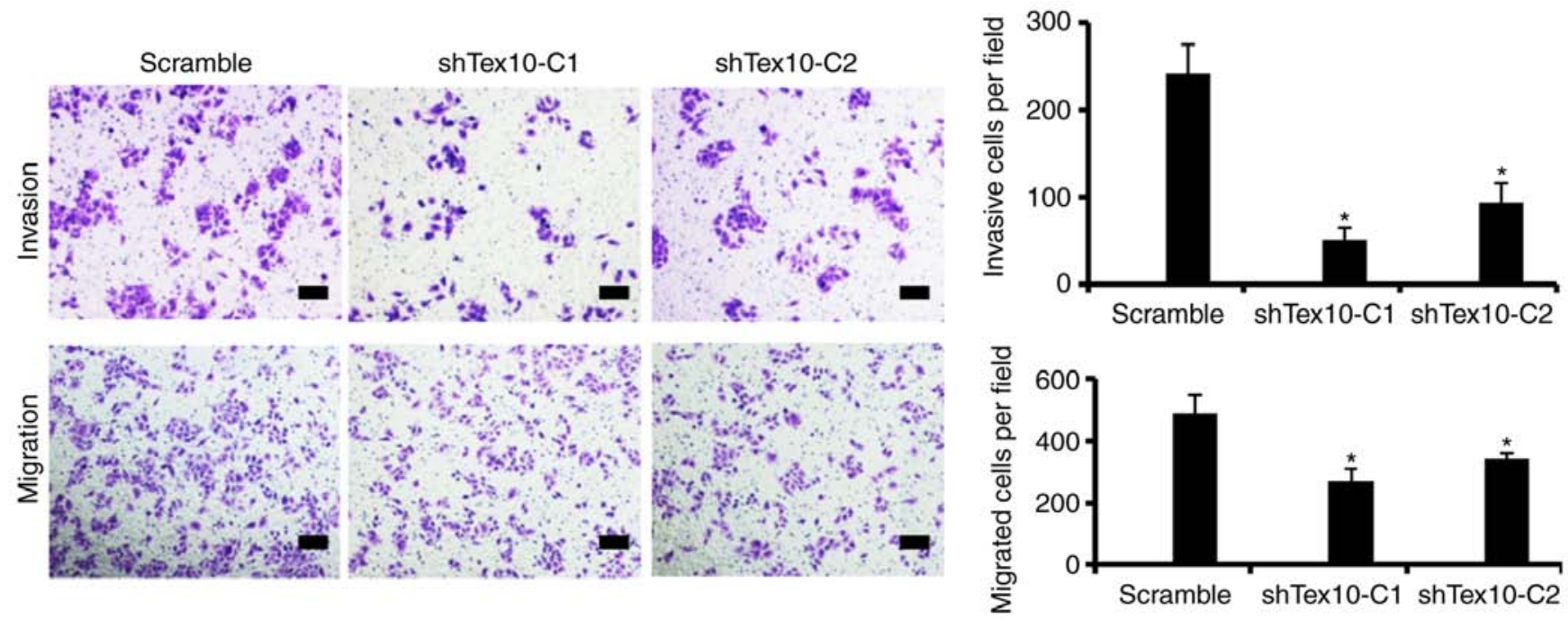

Figure 4. Silencing of Tex10 suppresses the migratory and invasive capabilities of the EC109 cells. The migratory and invasive capabilities of the EC109 cells were evaluated by using Transwell migration and invasion assays. Representative microscopic images of the bottom chamber are shown. The bar graphs represent the average number of migrated cells and invaded cells on the underside of the membrane. One-way ANOVA followed by the Bonferroni test was used to determine the statistical significance of the differences. ${ }^{*} \mathrm{P}<0.05$, significant difference vs. scramble group. Scar bar, $100 \mu \mathrm{m}$. Tex 10 , testis expressed 10 .

of the Wnt/ $\beta$-catenin pathway, including cyclin D1, c-Myc and TCF4, was assessed. As shown in Fig. 5D, the silencing of Tex10 markedly reduced the protein levels of cyclin D1, c-Myc and TCF4. Taken together, these results indicate that Tex10 may promote the EMT in ESCC via activation of the $\mathrm{Wnt} / \beta$-catenin pathway.

\section{Discussion}

Tex10 plays important roles in the regulation of transcription, the cell cycle and ribosome biogenesis. Most importantly, Tex10 functions as a key pluripotency factor that plays an essential role in esophageal squamous cell pluripotency and early embryonic development $(8,9)$. Although a previous study by our group indicated that Tex10 plays a distinct tumorigenic role in HCC by maintaining stem cell-like traits (10), the potential molecular mechanisms through which Tex10 exerts its effects on ESCC remain to be elucidated. To the best of our knowledge, the present study is the first to report the functional role of Tex10 in the regulation of the EMT process and stemness by activating Wnt/ $\beta$-catenin signaling.

CSCs are heterogeneous populations of tumor cells, which possess unlimited self-renewal ability and multi-lineage differentiation potential, and are responsible for tumor initiation, recurrence and chemotherapy resistance $(24,25)$. Therefore, CSCs are considered to be an ideal target for cancer therapy (26). A previous study by our group reported that Tex10 was involved in maintaining cancer stem cell properties in HCC (10). In the present study, it was demonstrated that Tex 10 was associated with CSC-like traits, including chemoresistance and the EMT phenotype. The knockdown of Tex10 suppressed the sphere-forming ability of EC109 cells and significantly downregulated the expression of CSC markers, including c-Myc, Bmi1, ABCG2, CD44 and CD24. Previous studies have suggested that Tex 10 plays a central role in the establishment and maintenance of ESC pluripotency $(8,9)$. The results of the present study demonstrated that the silencing of Tex10 impaired cell stemness through the reduction of the expression of Sox2, Nanog and Oct4. In addition, it was indicated that the knockdown of Tex10 in the EC109 cells enhanced the sensitivity of the cells to 5-fluorouracil. Taken together, these results suggest that Tex10 may be a potential target for overcoming chemoresistance in ESCC.

The activation of EMT contributes to the generation of CSC-like cells $(27,28)$, which is one of the major molecular mechanisms responsible for the enhanced migration and invasion during carcinogenesis $(29,30)$. The present study confirmed that the silencing of Tex10 substantially reduced ESCC cell migration and invasion, and Tex10 expression was associated with morphological changes and the expression of EMT markers; thesilencing of Tex 10 upregulated E-cadherin and downregulates vimentin, Slug, $\beta$-catenin expression in ESCC cells, suggesting that Tex10 promotes EMT in vitro.

During cancer progression, several signaling pathways are involved in the regulation of EMT, including tumor growth factor- $\beta$, Notch, STAT3, Hedgehog and Wnt/ $\beta$-catenin (31-35), leading to the promotion of tumor invasion and metastasis. Wnt/ $\beta$-catenin signaling plays an important role in promoting the self-renewal and tumorigenicity of CSCs in multiple cancer types, and contributes to EMT during cancer progression (36-38). However, to the best of our knowledge, there is available study to date on the association between Tex10 and Wnt/ $\beta$-catenin signaling in ESCC. The present study established that the silencing of Tex10 decreased the expression of $\beta$-catenin and the target genes, TCF4, cyclin D1 and c-Myc, suggesting that pharmacological targeting of Tex10 to block Wnt/ $\beta$-catenin signaling and inhibit EMT is an attractive strategy with which to prevent tumor metastasis in ESCC. The elucidation of the exact roles of Tex10 in the pathogenesis of ESCC and the molecular mechanisms through which Tex10 activates $\mathrm{Wnt} / \beta$-catenin signaling may contribute to a better understanding of cancer progression. Although the present 
A



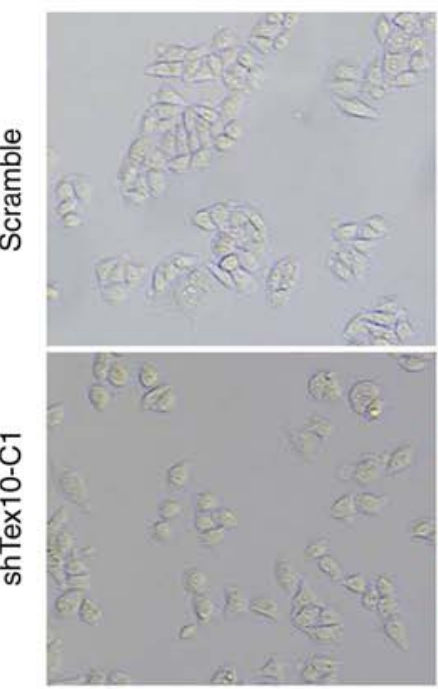

$\mathrm{B}$

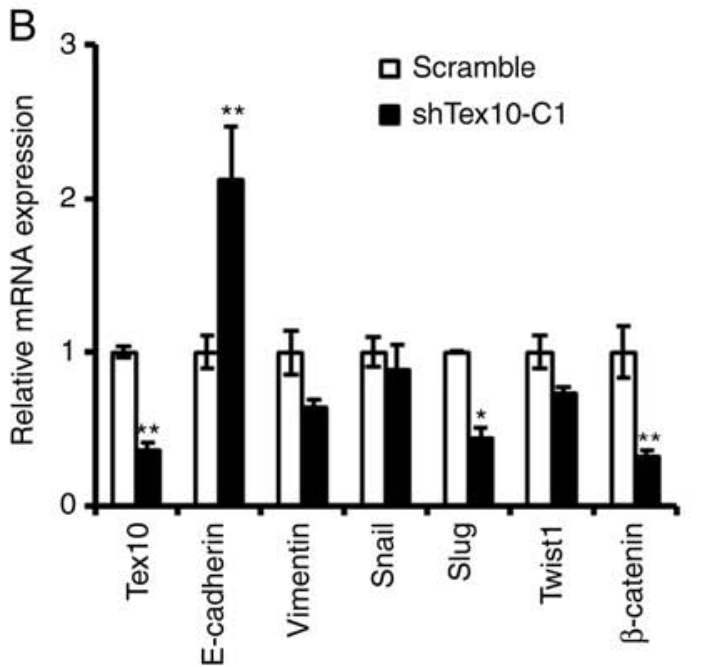

F-actin
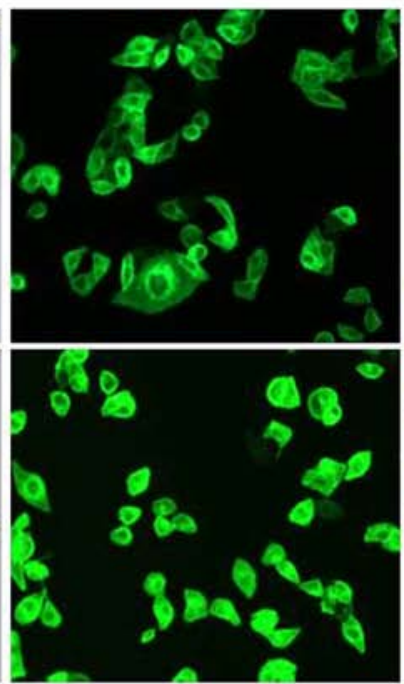

DAPI
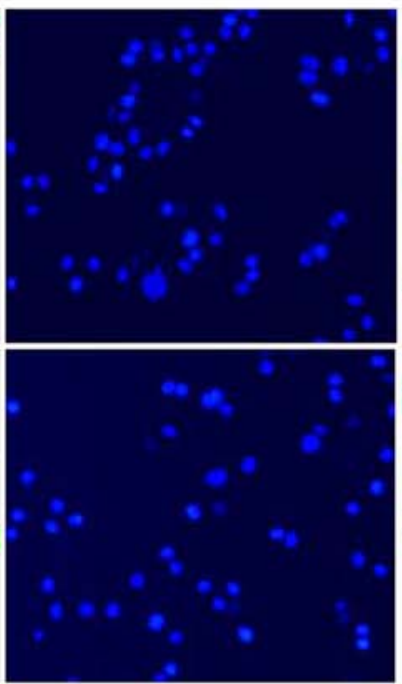

Merged
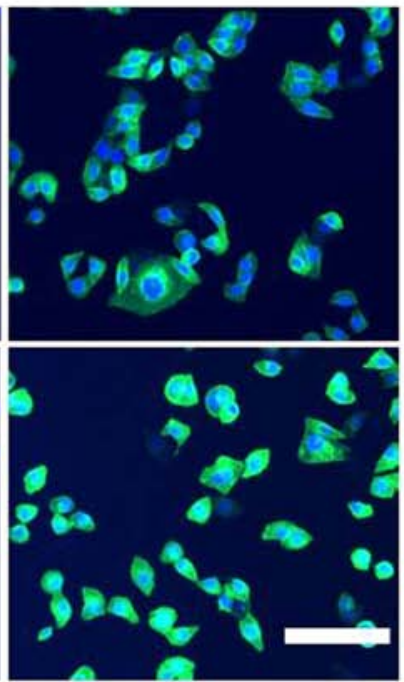

C

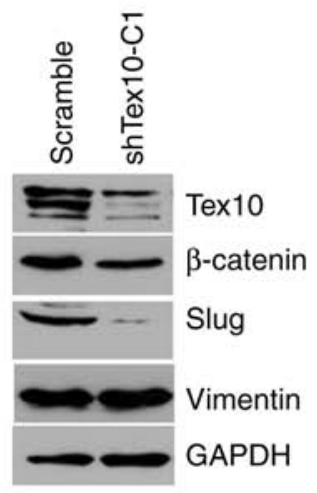

D

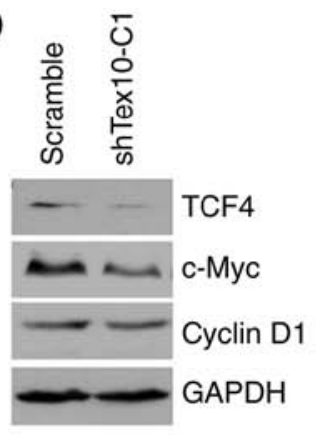

Figure 5. Tex10-regulated EMT markers. (A) Representative images of cytoskeleton showeing that Tex10 affected cellular morphology. Scar bar, $100 \mu \mathrm{m}$. (B) The mRNA expression levels of 5 EMT markers (E-cadherin, Vimentin, Snail, Slug, Twist1 and $\beta$-catenin) and Tex10 in EC109 cells were assayed by RT-qPCR. GAPDH was used as an internal control. The two-tailed unpaired Student's t-test was used to determine statistical significance. ${ }^{*} \mathrm{P}<0.05$ and ${ }^{* *} \mathrm{P}<0.01$, significant difference vs. scramble group. (C) The protein levels of EMT marker (Slug, $\beta$-catenin, Vimentin) and Tex10 in different groups of cells were assayed by western blot analysis. GAPDH was used as an internal control. (D) The protein levels of targets of the Wnt/ $\beta$-catenin pathway (TCF4, c-Myc and Cyclin D1) in different groups of EC109 cells were assayed by western blot analysis. GAPDH was used as an internal control. Tex10, testis expressed 10 .

study revealed the essential role of Tex10 in positively regulating $\beta$-catenin expression in ESCC, the exact molecular mechanisms underlying this process remain to be identified; thus, further studies are required in the future.

Collectively, the present study demonstrated that Tex10 may serve as a functional marker of CSCs in ESCC, and may potentially represent a valuable prognostic biomarker and therapeutic target for ESCC.

\section{Acknowledgements}

Not applicable.

\section{Funding}

This study was supported by the Project of the Education Department of Sichuan Province (grant no. 18ZB0214 to JB), the Innovation Project of Medical Scientific Research Youth in
Sichuan Province (grant no. Q18054 to XX) and the Bureau of Science and Technology and Intellectual Property Nanchong City, China (NSMC20170466 to XX, 18SXHZ0211 to XL, 18SXHZ0210 to RX).

\section{Availability of data and materials}

All data generated or analyzed during this study are included in this published article.

\section{Authors' contributions}

$\mathrm{XX}$ and GF conceived the and supervised the study; $\mathrm{XX}$ and RX designed the experiments; RX, XL and CY performed experiments; YZ, LD and JB developed new software and performed simulation studies; XL, DX, ZC, CY and KL analyzed the data; XX, RX and GF wrote the manuscript. All authors read and approved the final manuscript. 


\section{Ethics approval and consent to participate}

The study involving the use of human tissue was approved by the Ethics Committee of the North Sichuan Medical College (NSMC) and Ethical Committee of the Nanchong Central Hospital (Sichuan, China). Written informed consent was obtained from all subjects. All applicable international, national, and/or institutional guidelines for the care and use of animals were followed. All procedures performed in the studies were in accordance with the 1964 Declaration of Helsinki and its later amendments.

\section{Patient consent for publication}

Not applicable.

\section{Competing interests}

The authors declare that they have no competing interests.

\section{References}

1. Chen W, Zheng R, Baade PD, Zhang S, Zeng H, Bray F, Jemal A, Yu XQ and He J: Cancer statistics in China, 2015. CA Cancer J Clin 66: 115-132, 2016.

2. Chen W, Sun K, Zheng R, Zeng H, Zhang S, Xia C, Yang Z, Li H, Zou X and He J: Cancer incidence and mortality in China, 2014. Chin J Cancer Res 30: 1-12, 2018.

3. Torre LA, Bray F, Siegel RL, Ferlay J, Lortet-Tieulent J and Jemal A: Global cancer statistics, 2012. CA Cancer J Clin 65 87-108, 2015.

4. Pennathur A, Gibson MK, Jobe BA and Luketich JD: Oesophageal carcinoma. Lancet 381: 400-412, 2013.

5. Fanis P, Gillemans N, Aghajanirefah A, Pourfarzad F, Demmers J, Esteghamat F, Vadlamudi RK, Grosveld F, Philipsen S and van Dijk TB: Five friends of methylated chromatin target of prote in-arginine-methyltransferase[prmt]-1 (chtop), a complex linking arginine methylation to desumoylation. Mol Cell Proteomics 11 1263-1273, 2012

6. Castle CD, Cassimere EK and Denicourt C: LAS1L interacts with the mammalian Rix1 complex to regulate ribosome biogenesis Mol Biol Cell 23: 716-728, 2012.

7. Finkbeiner E, Haindl M and Muller S: The SUMO system controls nucleolar partitioning of a novel mammalian ribosome biogenesis complex. EMBO J 30: 1067-1078, 2011.

8. Ding J, Huang X, Shao N, Zhou H, Lee DF, Faiola F, Fidalgo M, Guallar D, Saunders A, Shliaha PV, et al: Tex10 coordinates epigenetic control of super-enhancer activity in pluripotency and reprogramming. Cell Stem Cell 16: 653-668, 2015.

9. Zhao W, Huang Y, Zhang J, Liu M, Ji H, Wang C, Cao N, Li C, Xia Y, Jiang Q and Qin J: Polycomb group RING finger proteins $3 / 5$ activate transcription via an interaction with the pluripotency factor Tex10 in embryonic stem cells. J Biol Chem 292 21527-21537, 2017.

10. Xiang X, Deng L, Xiong R, Xiao D, Chen Z, Yang F, Liu K and Feng G: Tex 10 is upregulated and promotes cancer stem cell properties and chemoresistance in hepatocellular carcinoma. Cell Cycle 17: 1310-1318, 2018.

11. Wang D, Plukker JTM and Coppes RP: Cancer stem cells with increased metastatic potential as a therapeutic target for esophageal cancer. Semin Cancer Biol 44: 60-66, 2017.

12. Ouzounova M, Lee E, Piranlioglu R, El Andaloussi A, Kolhe R, Demirci MF, Marasco D, Asm I, Chadli A, Hassan KA, et al: Monocytic and granulocytic myeloid derived suppressor cells differentially regulate spatiotemporal tumour plasticity during metastatic cascade. Nat Commun 8: 14979, 2017.

13. Pastushenko I and Blanpain C: EMT transition states during tumor progression and metastasis. Trends Cell Biol 29: 212-226, 2019.

14. Dongre A and Weinberg RA: New insights into the mechanisms of epithelial-mesenchymal transition and implications for cancer. Nat Rev Mol Cell Biol 20: 69-84, 2019.
15. Ishay-Ronen D, Diepenbruck M, Kalathur RKR, Sugiyama N, Tiede S, Ivanek R, Bantug G, Morini MF, Wang J, Hess C and Christofori G: Gain fat-lose metastasis: Converting invasive breast cancer cells into adipocytes inhibits cancer metastasis. Cancer Cell 35: 17-32.e16, 2019.

16. Xiang X, Deng L, Zhang J, Zhang X, Lei T, Luan G, Yang C, Xiao ZX, Li Q and Li Q: A distinct expression pattern of cyclin $\mathrm{K}$ in mammalian testes suggests a functional role in spermatogenesis. PLoS One 9: e101539, 2014.

17. Livak KJ and Schmittgen TD: Analysis of relative gene expression data using real-time quantitative PCR and the 2(-Delta Delta $\mathrm{C}(\mathrm{T})$ ) method. Methods 25: 402-408, 2001.

18. Maehara O, Suda G, Natsuizaka M, Ohnishi S, Komatsu Y, Sato F, Nakai M, Sho T, Morikawa K, Ogawa K, et al: Fibroblast growth factor-2-mediated FGFR/Erk signaling supports maintenance of cancer stem-like cells in esophageal squamous cell carcinoma. Carcinogenesis 38: 1073-1083, 2017.

19. Lu YX, Chen DL, Wang DS, Chen LZ, Mo HY, Sheng H, Bai L, Wu QN, Yu HE, Xie D, et al: Melatonin enhances sensitivity to fluorouracil in oesophageal squamous cell carcinoma through inhibition of Erk and Akt pathway. Cell Death Dis 7: e2432, 2016.

20. Iser IC, Ceschini SM, Onzi GR, Bertoni AP, Lenz G and Wink MR: Conditioned medium from adipose-derived stem cells (ADSCs) promotes epithelial-to-mesenchymal-like transition (EMT-Like) in glioma cells in vitro. Mol Neurobiol 53: 7184-7199, 2016

21. Zhang HF, Wu C, Alshareef A, Gupta N, Zhao Q, Xu XE, Jiao JW, Li EM, Xu LY and Lai R: The PI3K/AKT/c-MYC axis promotes the acquisition of cancer stem-like features in esophageal squamous cell carcinoma. Stem Cells 34: 2040-2051, 2016.

22. Hu X, Zhai Y, Kong P, Cui H, Yan T, Yang J, Qian Y, Ma Y, Wang F, Li H, et al: FAT1 prevents epithelial mesenchymal transition (EMT) via MAPK/ERK signaling pathway in esophageal squamous cell cancer. Cancer Lett 397: 83-93, 2017.

23. Chen HA, Kuo TC, Tseng CF, Ma JT, Yang ST, Yen CJ, Yang CY, Sung SY and Su JL: Angiopoietin-like protein 1 antagonizes MET receptor activity to repress sorafenib resistance and cancer stemness in hepatocellular carcinoma. Hepatology 64: 1637-1651, 2016.

24. Marquardt S, Solanki M, Spitschak A, Vera J and Pützer BM: Emerging functional markers for cancer stem cell-based therapies: Understanding signaling networks for targeting metastasis. Semin Cancer Biol 53: 90-109, 2018.

25. Loureiro R, Mesquita KA, Magalhães-Novais S, Oliveira PJ and Vega-Naredo I: Mitochondrial biology in cancer stem cells. Semin Cancer Biol 47: 18-28, 2017

26. Nagle PW, Plukker JTM, Muijs CT, van Luijk P and Coppes RP: Patient-derived tumor organoids for prediction of cancer treatment response. Semin Cancer Biol 53: 258-264, 2018.

27. Singh M, Yelle N, Venugopal C and Singh SK: EMT: Mechanisms and therapeutic implications. Pharmacol Ther 182: 80-94, 2018.

28. Chen L, Li YC, Wu L, Yu GT, Zhang WF, Huang CF and Sun ZJ: TRAF6 regulates tumour metastasis through EMT and CSC phenotypes in head and neck squamous cell carcinoma. J Cell Mol Med 22: 1337-1349, 2018.

29. Peng JM, Bera R, Chiou CY, Yu MC, Chen TC, Chen CW, Wang TR, Chiang WL, Chai SP, Wei Y, et al: Actin cytoskeleton remodeling drives epithelial-mesenchymal transition for hepatoma invasion and metastasis in mice. Hepatology 67: 2226-2243, 2018.

30. Xie K, Ye Y, Zeng Y, Gu J, Yang H and Wu X: Polymorphisms in genes related to epithelial-mesenchymal transition and risk of non-small cell lung cancer. Carcinogenesis 38: 1029-1035, 2017.

31. Natsuizaka M, Whelan KA, Kagawa S, Tanaka K, Giroux V, Chandramouleeswaran PM, Long A, Sahu V, Darling DS, Que J, et al: Interplay between Notch1 and Notch3 promotes EMT and tumor initiation in squamous cell carcinoma. Nat Commun 8: 1758, 2017.

32. Zhao D, Besser AH, Wander SA, Sun J, Zhou W, Wang B, Ince T, Durante MA, Guo W, Mills G, et al: Cytoplasmic p27 promotes epithelial-mesenchymal transition and tumor metastasis via STAT3-mediated Twist1 upregulation. Oncogene 34: 5447-5459, 2015.

33. Huang J, Xiao D, Li G, Ma J, Chen P, Yuan W, Hou F, Ge J, Zhong M, Tang Y, et al: EphA2 promotes epithelial-mesenchymal transition through the $\mathrm{Wnt} / \beta$-catenin pathway in gastric cancer cells. Oncogene 33: 2737-2747, 2014

34. Kim J, Hyun J, Wang S, Lee C and Jung Y: MicroRNA-378 is involved in hedgehog-driven epithelial-to-mesenchymal transition in hepatocytes of regenerating liver. Cell Death Dis 9: 721, 2018. 
35. Katsuno Y, Qin J, Oses-Prieto J, Wang H, Jackson-Weaver O, Zhang T, Lamouille S, Wu J, Burlingame A, Xu J and Derynck R Arginine methylation of Smad7 by PRMT1 in TGF- $\beta$-induced epithelial-mesenchymal transition and epithelial stem cell generation. J Biol Chem 293: 13059-13072, 2018.

36. Lee SH, Koo BS, Kim JM, Huang S, Rho YS, Bae WJ, Kang HJ, $\mathrm{Kim}$ YS, Moon JH and Lim YC: Wnt/ $\beta$-catenin signalling maintains self-renewal and tumourigenicity of head and neck squamous cell carcinoma stem-like cells by activating Oct4. J Pathol 234: 99-107, 2014.
37. Xiang D, Cheng Z, Liu H, Wang X, Han T, Sun W, Li X, Yang W, Chen C, Xia M, et al: Shp2 promotes liver cancer stem cell expansion by augmenting $\beta$-catenin signaling and predicts chemotherapeutic response of patients. Hepatology 65: 1566-1580, 2017.

38. Chai S, Ng KY, Tong M, Lau EY, Lee TK, Chan KW, Yuan YF, Cheung TT, Cheung ST, Wang XQ, et al: Octamer 4/microRNA-1246 signaling axis drives Wnt/ $\beta$-catenin activation in liver cancer stem cells. Hepatology 64: 2062-2076, 2016.

(i) $\ominus$ This work is licensed under a Creative Commons Attribution-NonCommercial-NoDerivatives 4.0 International (CC BY-NC-ND 4.0) License. 